\title{
Kawung: Acculturation of Culture Decorative Motif Development Java Impact of Indian and Chinese Trade in IX-XV AD Centuries
}

\author{
Siti Maziyah \\ \{mazy_muiz@yahoo.com\} \\ Universitas Diponegoro, Indonesia
}

\begin{abstract}
Trade in India and China in the IX-XV AD centuries in Java led to cultural acculturation recorded on decorative motifs worn by certain statues. One of the decorative motifs is Kawung, which is believed to be a typical Javanese ornamental motif. The problem is, how the process of acculturation of this Kawung motif in Java? The method for tracing this problem uses historical archeology, which uses archaeological data in the form of inscriptions, statues, and literary texts, to trace the acculturation of Kawung ornamental motifs in Java. In addition, the results of similar studies are also used to strengthen the analysis of the existence of cultural acculturation among Java, India and China, related to the Kawung motif. The results show that the Kawung motif is one of the ornamental motifs that has a high exotic value, so that it is liked and developed throughout Asia, not least on Java.
\end{abstract}

Keywords: Kawung, Javanese, Indian, Chinese, acculturation, trade.

\section{Introduction}

Since the seventh century, Java was one of the trade centers in Southeast Asia [1][2][3]. This causes many traders to arrive on Java Island by bringing various types of trading commodities. They came from among others India and China, as the center of world civilization [4][1][5]. The longer the trade in the sea of the archipelago becomes increasingly crowded [4][1][2][3][5]. The long intensive relationship between nations turned out to lead to cultural acculturation, among others seen in the Kawung motifs worn by several statues in certain temples in Java. This motif is still sustainable and is still popular by the Javanese people. So far, the Kawung motif is understood as one of the Javanese batik motifs, and has a Javanese philosophy as well. How did the Kawung acculturation process take place in Java?

\section{Research Methods}

The method for tracing this problem uses archaeological data in the form of inscriptions, statues, and literary texts related to Kawung motifs. In addition, the results of similar studies are also used to strengthen the analysis of the existence of cultural acculturation among Java, India and China, related to the Kawung motif. Based on the archeological data, it can be 
analyzed the process of acculturation of Kawung motifs in Javanese society, so that the Javanese people feel that this motif is their motive.

\section{Results and Discussion}

\subsection{The Origin of Kawung Motif}

In connection with Kawung motifs, Green [6] in his research links the use of medallion decorative motifs found in Chinese silk fabrics and Indian cotton fabrics with relief medallions found on the temple walls in Angkor concluded that both types of luxury fabrics were used in the Khmer palace. Decorative motifs found in the two types of luxury fabrics, in the Khmer, were then transformed into temple wall hangings. The luxurious motif was used to decorate the temple as the home of the gods. One example of a medallion motif that is transformed into reliefs based on decorative fabric motifs is as shown below.

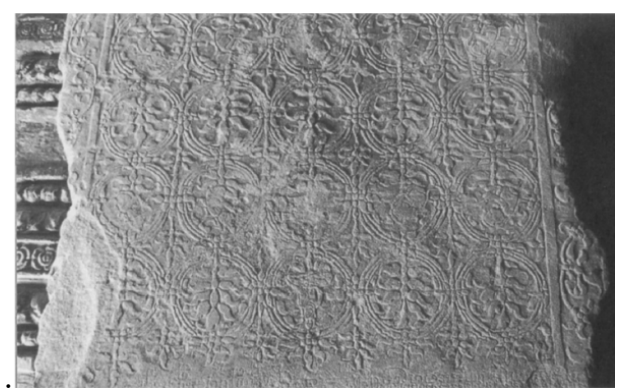

Fig. 1. Medallion of Preah Khan [6].

Among the various medallion motifs, Green [6] states that the motif "cash" or in the form of intersecting circles, which in Java is commonly called Kawung, is actually an ornamental motif that was commonly represented on cultural objects in China at the beginning AD. The motif was used to decorate ceramics, carvings, fabrics, and paintings [6][7]. As a result of cultural contact with China and India, especially the trade in luxury fabrics made of silk and cotton which have beautiful motifs, the motifs found on the fabric in Khmer were used to decorate the walls of the temple which was built in the twelfth century. Various circular motifs called medallion motifs are carved on the walls of the temple, such as the "cash" motif [6] as shown in the following figure.
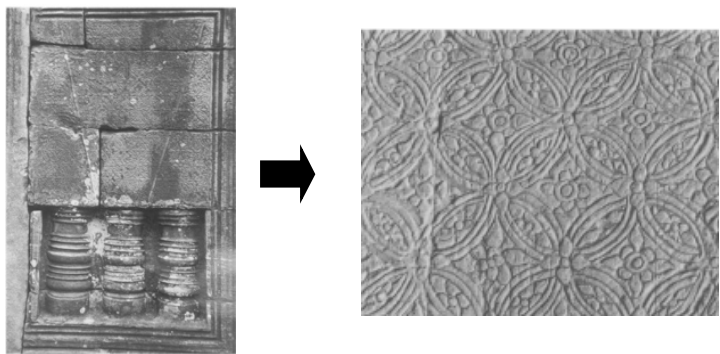

Fig. 2. "Cash" Motif in Preah Khan Angkor [6] 
In India, a similar motif is called the Gujarati motif, and is one of the most popular trading commodities in the Egyptian market from the third century to the fifth century. One of the Gujarati cotton fabrics with kawung motifs found on the Egyptian market is thought to have originated in 1260 to 1330 [8] Following are the Gujarati fabric motifs found in the Egyptian market.

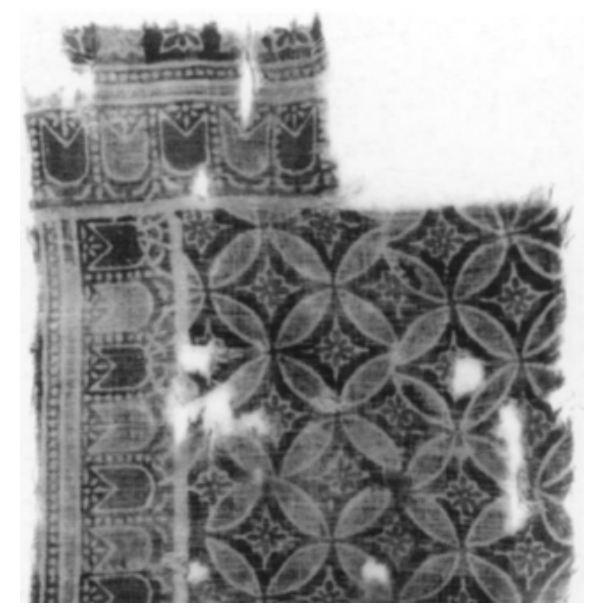

Fig. 3. Gujarat Textile for XIII Century Egypt [8].

Based on both archaeological evidence from Khmer and India relating to kawung patterned fabrics, it can be seen that the motifs, both of silk and cotton, are in great demand by the market and are said to be fabrics that have luxurious motifs. The motif spread throughout Asia because of trade contacts between them. Thus, it can be seen that actually this kawung motif originated from China and India and spread in various places in Asia by them through trade

\subsection{Acculturation of Kawung Motifs on Javanese Cultural Results}

Trade contacts between India and China on Java have been ongoing since the beginning of our era [7][9] . At that time only Indians made direct trade contacts with Java. The Chinese made direct trade contacts with Java only after Nanhay was used as a maritime silk route in the seventh century [1][2][3]. The long relationship between India, China and Java led to the acculturation of the culture of making Kawung motifs that can be shown visually on statues, mentioned in inscriptions and literature, and finally these motifs belong to the Javanese self by giving meaning and philosophical meaning and developing forms Kawung motives are in accordance with the Javanese people's mind.

\subsubsection{Acculturation of Kawung Motif Culture on Fabrics Used in Statues of the Ninth to Fifteenth Century}

Kawung motifs on Java were first seen in the cloth worn by the Ganesha statue in the Prambanan Temple complex, which is thought to have been made in the ninth century. The Kawung motif carved on the cloth worn by Ganesha shows that the Old Javanese people were 
familiar with the motif and understood who was allowed to wear it. Based on the previous discussion, in Khmer, this motif was used by the court and used to decorate the temple. Ganesha is the son of Lord Shiva, thus Ganesha is one of the gods, so it is permissible to wear a Kawung patterned cloth. The motive is still simple as shown in figure 4.

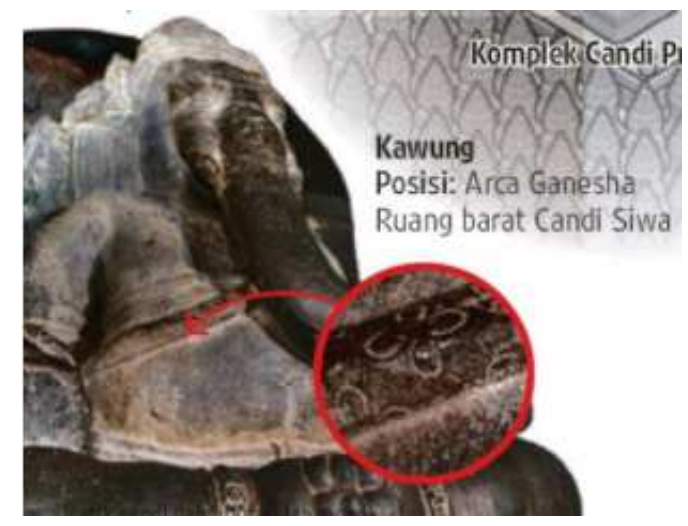

Fig. 4. Kawung Worn by the Ganesha Statue in The Prambanan Temple Complex in Prambanan [10]

This Kawung motif is also found on the cloth worn by the Drawapala statue in the very backyard of Penataran Temple in Blitar. This temple was made in the twelfth century until the fourteenth century. The shape of the motif is very beautiful, visible geometric motifs such as those found in Preah Khan Angkor and Gujarat textiles.

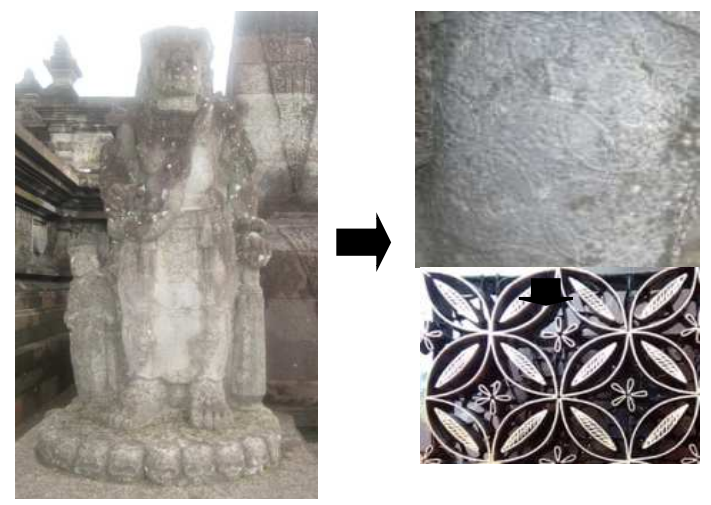

Fig. 5. Kawung Worn by The Drawapala Statue in The Penataran Temple in Blitar [7][11].

The most beautiful kawung motif from the Hindu Buddhist period in Java is as used by the Kertarajasa statue in the Sumberjati Blitar Temple below [12]. 


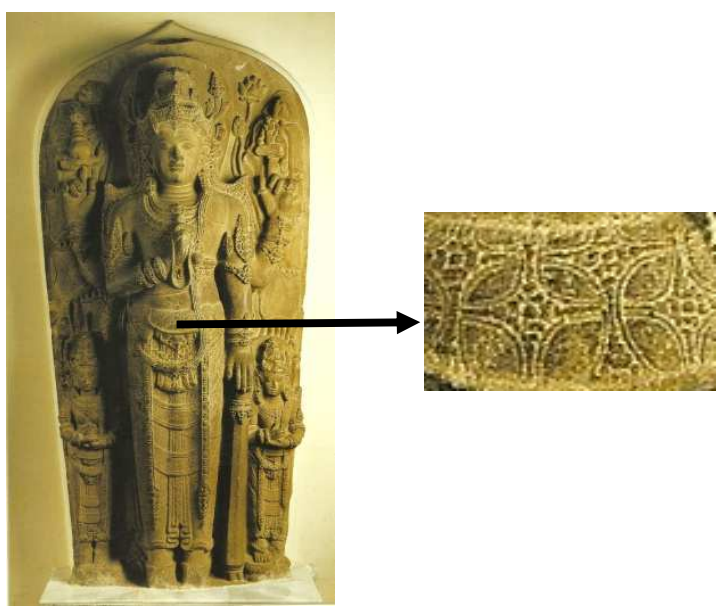

Fig. 6. Kawung Worn by Kertarajasa at the Simping Temple in Blitar [7][12].

The Kertarajasa statue above is a representation of the first king of Majapahit. On that statue, he is described as Harihara, which is a blend of Shiva and Vishnu in Hinduism [12]. It is therefore not surprising that the depiction of the Kawung motifs worn by the Kertarajasa statue represents the clothing worn by deities in Hinduism. This statue is thought to originate in the thirteenth century.

Rouffaer and Juynboll [13] said that the kawung motif on the cloth worn by the Kertarajasa statue represented that the ancient Javanese community in the thirteenth century had known two-pronged canting to draw a double lines. It shows that the Javanese people of the thirteenth century already had a high level of culture. Sedyawati [13] said that Javanese society has two peaks of classical culture, namely in the ninth to tenth century during the Hindu Mataram Kingdom and in the thirteenth century during the Singasari Kingdom. It seems that the condition is in accordance with the archeological evidence as shown by the Kertarajasa statue.

\subsubsection{Kawung Motifs on Literary Inscriptions and Manuscripts}

Definition the term kawung in Old Javanese society includes three things, first, as a type of fabric motif; second, to call the dried palm leaves (Arenga Pinnata); third, one type of designation for members of watek $i$ jro or the king's assistant in the palace [14]. The term kawung was already mentioned by the inscriptions at the beginning of the tenth century, namely the Gulung Gulung Inscription and the Linggasuntan Inscription. However, the information contained in the two inscriptions relates to the notion of kawung as dried palm leaves (Arenga Pinnata) and as a member of the watek $i$ jro.

The definition of kawung as a fabric motif is recorded in ancient Javanese literary manuscripts of the twelfth to fifteenth century [14] as in the table 1.

Table 1. Kawung Motives in Literary Texts

\begin{tabular}{|l|l|c|}
\hline No & \multicolumn{1}{|c|}{ Name } & Century \\
\hline 1. & Bhāratayuddha & XII \\
\hline 2. & Bhomakawya & XII \\
\hline 3. & Arjunawijaya & XIV \\
\hline
\end{tabular}




\begin{tabular}{|l|l|c|}
\hline 4. & Ranggalawe & XV \\
\hline 5. & Kidung Harsawijaya & XV \\
\hline 6. & Kidung Sunda & XV \\
\hline 7. & Waybang Wideha & XVI \\
\hline 8. & Malat & XVIII \\
\hline
\end{tabular}

Based on the table it can be seen that the term kawung is used to refer to cloth motifs, which have been recorded in literary texts, from the twelfth to eighteenth century. This shows that this motif remained in demand by the Javanese community for a long time, that is, for six centuries.

\subsubsection{Acculturation of Kawung Motifs on Fabrics}

Acculturation is a process undertaken by an individual or a nation in response to the coming of a new culture into its own culture. The factors that influence it are the contact between cultures in a long time, the mutual influence of culture, and the change in culture itself. This also happened to Kawung motifs in Java.

Based on the above discussion, it can be seen that this motif was originally brought and spread to various places in Asia by the Chinese and Indian people since the beginning of our era, among others as a motif on cloth. This motif turned out to be attractive to nations in Asia so that this motif was then emulated by various Asian nations such as in the Khmer and in Java. As a result of the long-standing cultural contact between the spreaders of this motif with the Javanese, this motif was finally interpreted according to the Javanese mindset and developed into various types of Kawung variants.

So far, the Javanese people believe that the Kawung motif is one of the results of their original culture. According to them, the form of the Kawung motif depicts the fruit kolangkaling (Arenga Pinnata) which are cleaved [10][15] as in Figure 6.

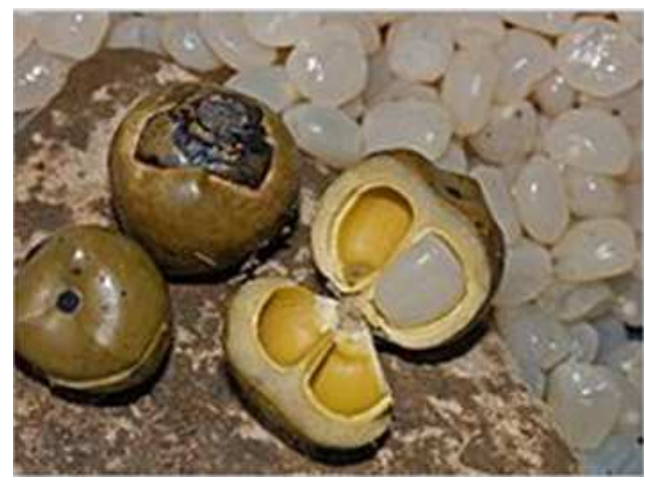

Fig. 7. Kaling Kolang (Arenga Pinnata) Split [10].

Based on the definition above, the shape of the Kawung motif is composed of elliptical shapes whose composition extends diagonally sloping left and right alternately and arranged repeatedly, or are intersecting circles [15]. Therefore, Green [6] called the motive with the motive "cash". The picture is as below. 

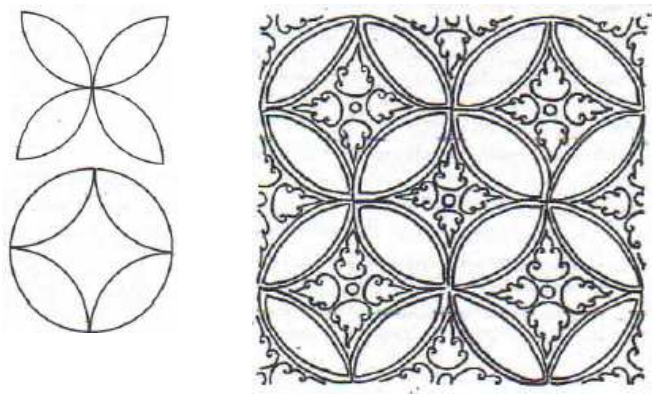

Fig. 8. Kawung Motifs [15].

The philosophical meaning of this Kawung motif according to the Javanese describes the structure of the universe. The center of the crossing is the source of energy and miniature from the universe. This Kawung motif is a representation of the principle of the mandala, namely the composition of the four cardinal directions with one center. In Javanese society's concept the concept is called "sedulur papat lima pancer". This concept originates from Javanese Hindu culture which has an understanding that continues to develop into the Islamic era. At first the understanding of this concept was the alignment between the small universe (humans and microcosms) and the large universe (humans with macrocosms). Understanding the concept of "sedulur papat" in the big universe is the four cardinal directions, namely east, south, west, and north. While the "pancer" or middle is the self or heart of man himself [16].

At first the kawung motif was only permitted to be worn by gods, kings or the royal family [16], as seen in the three examples of the statue above. Ganesha is one of the gods in Hinduism, he is the son of Lord Shiva. Drawapala in Penataran Temple guarded the holiest temple courtyard in the backyard. The Kertarajasa statue in Blitar Simping Temple is an embodiment of Harihara, a combination of Lord Shiva and Vishnu. Thus, the three statues explain the function of the Kawung motif which is only used by the gods, kings, and the royal family or related to the king.

In the world of puppetry, the Kawung motif is used by Ki Lurah Semar and his children. In the world of wayang, they are ordinary people who have wisdom and wisdom like gods [16]. Thus, it can be seen that the Kawung motifs should not be used by just anyone, but should be used by people who have the wisdom and wisdom as the gods and kings.

Until now Kawung is still known as one of the classic batik motifs that is still in demand by Javanese people. Even this Kawung has various variants of motifs that develop in Javanese society [15][16][17], among others as in the table 2 .

Table 2. Development of Kawung Motif Variants

\begin{tabular}{|c|l|l|}
\hline No & \multicolumn{1}{|c|}{ Type } & \multicolumn{1}{c|}{ Motif Name } \\
\hline 1. & By size & Kawung Picis \\
\hline & & Kawung Bribil \\
\hline & & Kawung Sen \\
\hline & & Kawung Kemplong \\
\hline 2. & Based on Design & Kawung Beton \\
\hline & & Kawung Cacah Gori \\
\hline & & Kawung Geger \\
\hline & & Kawung Kopi/Sari \\
\hline & & Kawung Sekar Ageng \\
\hline & & Kawung Semar \\
\hline
\end{tabular}




\begin{tabular}{|c|c|c|}
\hline \multirow[t]{2}{*}{3.} & \multirow{2}{*}{$\begin{array}{l}\text { Based on } \\
\text { Combinations }\end{array}$} & Kawung Buntal \\
\hline & & Kawung Kembang \\
\hline & & Kawung Seling \\
\hline
\end{tabular}

Making motifs is related to the creativity of artists, so it does not rule out the emergence of new motifs related to this kawung. Like the motif of Kawung Sawo Beludru, Kawung ukel, Kawung winarno, and so on [17].

\section{Conclusion}

Based on the discussion above, it can be concluded that culture is dynamic, always moving and influencing people or communities affected. As is the case with the Kawung motif, this motif originated from the centers of world civilization, namely China and India. As a result of intensive and prolonged trade contacts, cultural acculturation was possible in the Kawung motif in Java. The motives that were originally brought by Indian foreign traders to Java, eventually due to long cultural contacts caused the motifs were also favored by the Javanese people, even those motifs as if they belonged to the Javanese people as indicated by the meaning and philosophical value of the kawung motif according with the Javanese mindset.

\section{References}

[1] L. M. S. R. Qingxin, Traslater: William W. Wang. Cina: China Intercontinental Press, 2006.

[2] W. Gungwu, "The Nanhai Trade: A Study of the Early History of Chinese Trade in the South China Sea," JMBRAS, vol. 31, no. 3, pp. 1-135.

[3] Kenneth R Hall, A History of Early Southeast Asia: Maritime Trade and Societal Development, 100-1500. USA: Rowman and Littlefield Publisher Inc, 2011.

[4] J. W. Christie, "Javanese Markets and the Asian Sea Trade Boom of the Tenth Centuries A.D.," J. Econ. Soc. Hist. Orient., vol. 41, no. 3, pp. 344-381, 1998.

[5] S. Maziyah, Imports Fabric at Java in 12th - 14th Centuries: Impacts of Maritime Trade Route in Southeast Asia, vol. 23. Amerika: American Scientific Publishers, 2017.

[6] G. Green, “Angkor Vogue Sculpted Evidence of Imported Luxury Textiles in the Courts of Kings and Temples," J. Econ. Soc. Hist. Orient, vol. 50, no. 4, pp. 424-451, 2007.

[7] S. Maziyah, "Penetrasi Budaya Wargee Dalem dan Warga Kilalan dalam Kontruksi Masyarakat Jawa Kuna," Endogami J. Ilm. Kaji. Antropol., vol. 2, no. 2, pp. 192-202.

[8] R. Barnes, "Indian Textiles for Island Taste: Gujarati in Eastern Indonesia," Ars Orient., vol. 34, pp. 134-149, 2004.

[9] A. Prasetyo, Bagyo dan Calo, "Pantai Utara Bali Lokasi Strategis Jaringan Perdagangan Awal di Kawasan Asia." .

[10] "Sejarah Batik Kawung.".

[11] Siti Maziyah, "Sumberdaya Budaya Arkeologi : Tangible, Intangible, Atau Keduanya ?"

[12] E. al. Hilda Soemantri, Indonesia Heritage: Seni Rupa. Jakarta: Grolier Internasional, 2002.

[13] R. dan H. H. Juynboll., De Batik-Kuns in Nederlandsch Indië en Haar Geschiedenis. Utrecht: Uitgave van A. Costhoek, 1914.

[14] P. . Zoetmulder, Kamus Jawa Kuna-Indonesia. Translater: Darusuprapta and Sumarti Suprayitna. Jakarta: Gramedia Pustaka Utama, 2000.

[15] S. Susanto, Seni Kerajinan Batik Indonesia. Yogyakarta: Balai Penelitian Batik dan Kerajinan, Lembaga Penelitian dan Pendidikan Industri, Departemen Perindustrian Republik Indonesia, 
1973.

[16] A. Kusrianto, Batik-Filosofi, Motif, dan Kegunaan. Yogyakarta: C.V. Andi Offset, 2013.

[17] S. S. Samsi, Teknik dan Ragam Hias Batik Yogya \& Solo. Yogyakarta: Yayasan Titian Masa Depan (Titian Foundation), 2011. 